\title{
VESSEL WAKE INDUCED SEDIMENT MOBILITY AT EAGLE HARBOR, WASHINGTON, USA
}

\author{
David R. Michalsen ${ }^{1}$ Zeki Demirbilek ${ }^{2}$ and Okey Nwogu ${ }^{3}$
}

\begin{abstract}
Eagle Harbor is a small natural harbor located in central Puget Sound on the eastern side of Bainbridge Island, Washington State, USA. Over a period of about 80 years, the harbor was severely contaminated. Approximately 28.3 hectares of the contaminated harbor were capped with dredged and upland sediments from 1993 to 2008 . Recent monitoring data has concluded portions of the subtidal cap has eroded and may not be physically stable. Erosion in the vicinity of the car passenger ferry sailing line suggests the cap material may not be of sufficient size to achieve the objectives of providing a physical barrier for chemical isolation. Here, a two-dimensional finite difference model using a coupled Boussinesq-Panel method is used to investigate bed shear stresses on the existing sediment cap to analyze cap stability. Model results indicate the subtidal cap experiences over $100 \mathrm{~Pa}$ of bed stress within a 30 meter swath of the ferry sailing line. These bed stresses significantly exceed the critical shear stress of the original cap material indicating the cap is not physically stable.
\end{abstract}

Keywords: vessel wake; Boussinesq modeling; sediment mobility; sediment capping

\section{INTRODUCTION}

Eagle Harbor is a small natural harbor located on the eastern side of Bainbridge Island in Washington State. Over a period of about 80 years, the harbor was severely contaminated by hazardous chemicals released from the Wyckoff Company creosote wood treatment facility and several shipbuilding facilities. The Wyckoff/Eagle Harbor facility was designated a Superfund site in 1987. The U.S. Environmental Protection Agency (USEPA) partnered with the U.S. Army Corps of Engineers (USACE), Washington State Department of Transportation (WSDOT), Washington State Department of Ecology (WSDOE), and the Association of Bainbridge Island Communities to clean up the harbor and restore the marine ecosystem. Approximately 28.3 hectares (70 acres) of the contaminated harbor were capped with clean sediments. The sediment caps are monitored to ensure that buried toxins are not re-released into the marine environment. As listed in Table 1 and displayed in Figure 1 the Wyckoff/Eagle Harbor project sediment caps were constructed in different phases beginning in 1993 with the subtidal Phase I cap and most recently in 2008 with the construction of the Exposure Barrier System (EBS) on West Beach located on the southern harbor shoreline.

\section{OBJECTIVES}

A primary objective of the USEPA's Operations, Maintenance and Monitoring Plan (OMMP) for the Wyckoff/Eagle Harbor Superfund Site is to evaluate the physical stability of the sediment chemical isolation cap over time. Bathymetric survey data collected in 2005 showed evidence of sediment cap erosion under the WSDOT car/passenger ferry sailing line (Figure 2). Additionally beach profile adjustment on the EBS was observed since 2008 (Figure 3). Therefore, USEPA tasked the USACE to conduct a comprehensive hydrodynamic study investigating the physical stability of the sediment chemical isolation cap. Tidal currents and wind wave generated currents were found to have little influence on the physical stability of the Phase I cap. However wind waves likely contribute to episodic swash zone transport on the EBS in the upper intertidal region (HDR et al 2012). However, bathymetric and sediment core data indicated ferry wake could potentially be a more significant factor on cap stability. Additionally the frequency of ferry traffic in the harbor suggested the processes were important to understand so appropriate action could be taken. The following manuscript summarizes the data collection, vessel wake numerical modeling, engineering analysis, and conclusions of the study.

\footnotetext{
${ }^{1}$ U.S. Army Corps of Engineers, Seattle District, PO Box 3755, Seattle, WA, 98124, USA david.r.michalsen@usace.army.mil

2 U.S. Army Corps of Engineers, Engineer Research and Development Center, Coastal Hydraulics Laboratory, 3909 Halls Ferry Road, Vicksburg, MS, 39180, USA. zeki.demirbilek@erdc.dren.mil

${ }^{3}$ University of Michigan, Dept. Naval Architecture and Marine Engineering, 2600 Draper Road, Ann Arbor, MI 48109. onwogu@engin.umich.edu
} 


\section{SITE CONDITIONS}

Eagle Harbor has an area of 186.2 hectares (460 acres) at mean higher water (MHW) and measures approximately $2.8 \mathrm{~km}(1.75$ miles $)$ long by $1.2 \mathrm{~km}(0.75$ miles $)$ wide. Water depths range from $15.2 \mathrm{~m}$ (50 feet) near the eastern portion of the harbor to intertidal mud flats at mean lower low water (MLLW) in the western end. Approximately 23 percent of the harbor is tidal flats between MLLW and MHW elevations. The harbor mouth is oriented toward the southeast. An extensive shoal area, about $244 \mathrm{~m}$ (800 feet) long with water depths between 0 and $3.3 \mathrm{~m}$ (10 feet), extends into the harbor from the point at the site of the former Wyckoff Co. wood treatment facilities and defines the eastern side of the entrance channel. The channel wraps around this shoal to the southwest at a point east of the ferry terminal and follows the general alignment of the Harbor

The sediment cap shown in Figure 2 was constructed in multiple phases starting in 1994 and consists of sediment ranging from silt to gravel in depths ranging from subtidal to upper intertidal.

(CH2MHILL 2007). The mean diurnal tidal range is $2.3 \mathrm{~m} \mathrm{(7.7)} \mathrm{feet} \mathrm{and} \mathrm{is} \mathrm{nearly} \mathrm{identical} \mathrm{to} \mathrm{Seattle,}$ Washington. The tidal currents are weak in magnitude, less than 0.5 meters per second ( 1 knot), and the site is fairly sheltered from wind generated waves due the harbor geometry. The harbor is actively used by recreational vessels and is home to the WSDOT Bainbridge Island to Seattle vehicle/passenger ferry.

\section{DATA COLLECTION}

Two bottom mounted stations were deployed for one month in September 2010 to collect wave, current, water level, temperature, and total suspended solids (TSS) data. Station 1 (S1) was located near the harbor entrance at a depth of 12.2 meters (40 feet) mean lower low water (MLLW) immediately east of the 1994 Phase I cap. Station 2 (S2) was located immediately offshore of the 2008 Exposure Barrier System shoreline on West Beach at a depth of 4.6 meters (15 feet) MLLW, as shown in Figure 1. It was necessary to plan a sampling scheme to capture inbound and outbound wakes generated by the WSDOT ferries through Eagle Harbor. The sampling interval of pressure sensors was 5 minutes to ensure both inbound and outbound ferry transits were captured.

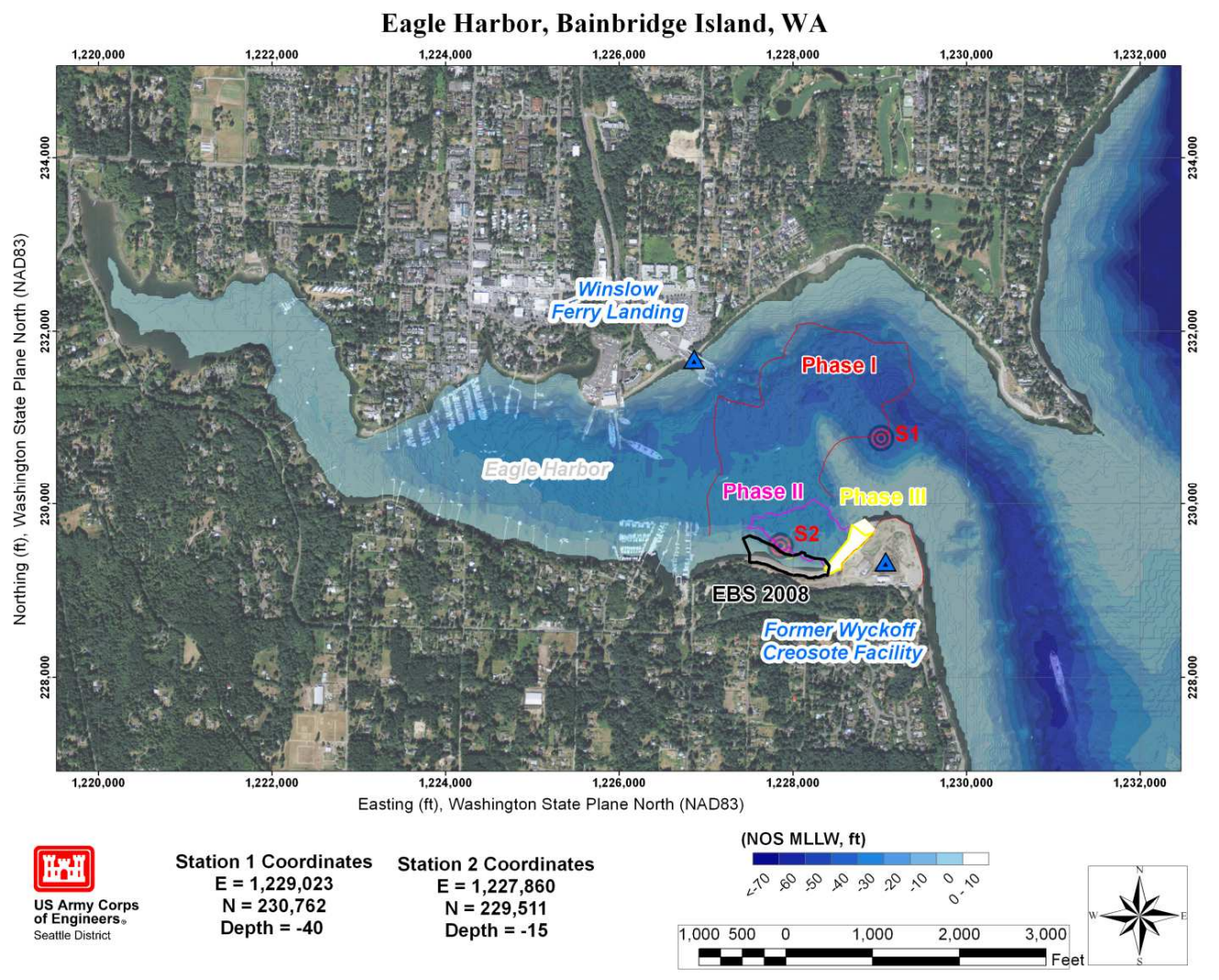

Figure 1. Eagle Harbor, Bainbridge Island, Washington State, USA 


\begin{tabular}{|l|l|}
\hline \multicolumn{2}{|l|}{ Table 1. Chronology of activities at the Wyckoff Eagle Harbor Project } \\
\hline $\begin{array}{l}\text { The Wyckoff/Eagle Harbor site was added to the National Priority } \\
\text { List (NPL) }\end{array}$ & 1987 \\
\hline Completion of the Remedial Investigation (RI) & 1989 \\
\hline Completion of the Feasibility Study (FS) for Eagle Harbor & 1991 \\
\hline $\begin{array}{l}\text { Construction of Phase I sand cap over subtidal contaminated } \\
\text { sediments }\end{array}$ & $1993-1994$ \\
\hline Removal of in-water structures (e.g., piers and pilings) & $1998-1999$ \\
\hline Installation of sheet pile wall around upland site & $1999-2001$ \\
\hline Intertidal investigation around the Wyckoff facility & $1999-2002$ \\
\hline Construction of Phase II subtidal cap & $2000-2001$ \\
\hline Construction of Phase III subtidal nearshore and intertidal cap & $2001-2002$ \\
\hline Installation of sheet pile wall around upland site & $1999-2001$ \\
\hline $\begin{array}{l}\text { Habitat mitigation beach on West Beach and extension of Phase III } \\
\text { subtidal nearshore and intertidal cap. }\end{array}$ & $2001-2002$ \\
\hline Construction of the West Beach Exposure Barrier System & 2008 \\
\hline
\end{tabular}

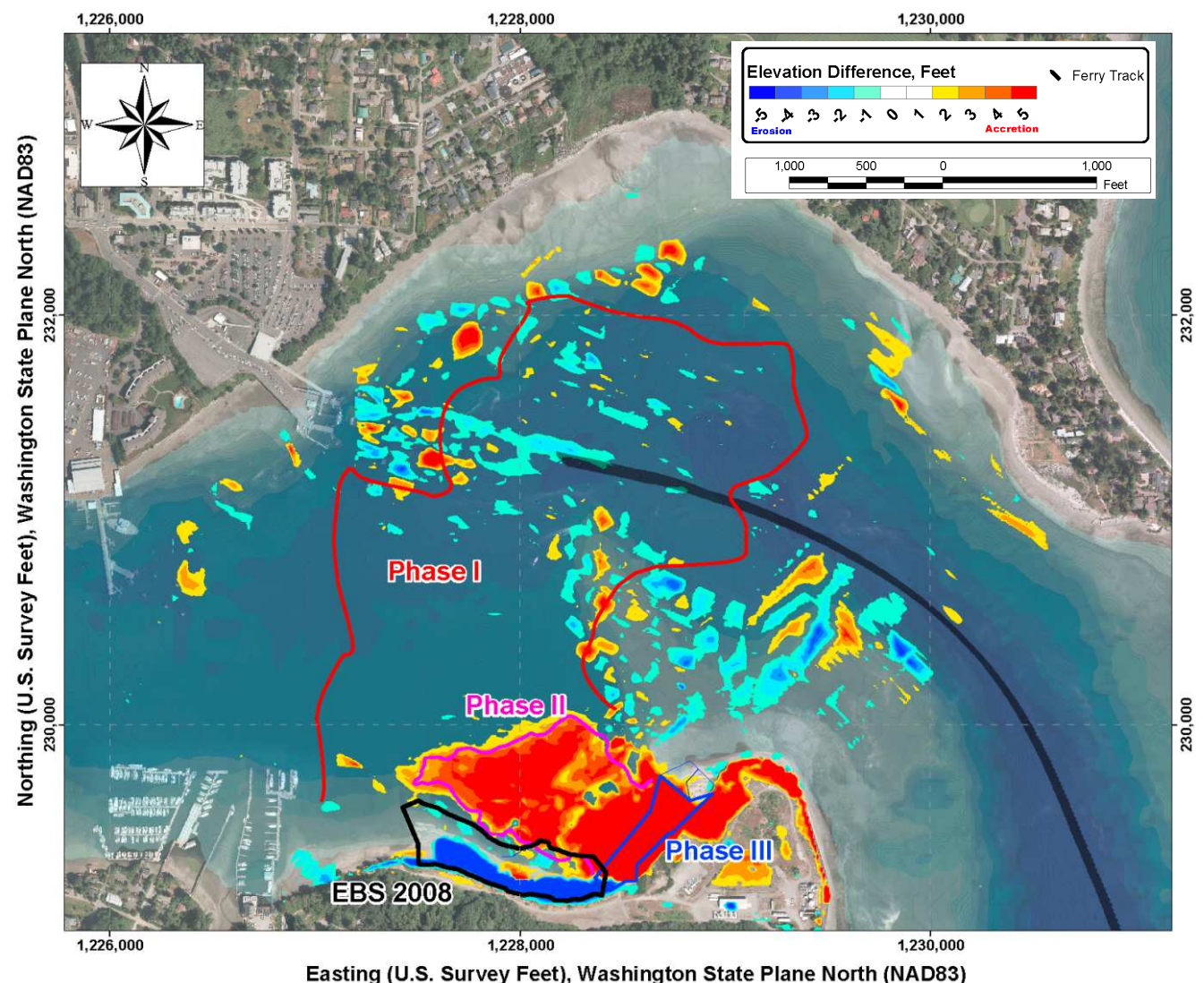

Figure 2. Bathymetric change over sediment caps from 1999 to 2005 (note ferry sailing line shown in black)

The measured bin averaged velocities at $\mathrm{S} 1$ were less than $25 \mathrm{~cm} / \mathrm{s}$ and exhibited primary northeast-southwest directionality. The measured bed velocities at $\mathrm{S} 2$ were less than $10 \mathrm{~cm} / \mathrm{s}$ and exhibited a primary northwest-southeast directionality which closely parallels the shoreline orientation. Outbound ferry transits produced the largest wave heights recorded at S1. The observed wake showed a large water level drawdown followed by shorter period diverging waves. Figure 4 shows the 
measured water surface elevation for a typical outbound transit measured at S1 which measured a significant wave height and peak wave period of $H_{s}=0.15 \mathrm{~m}$ and $T_{p}=4$ seconds respectively. Inbound ferry transits show a signature of diverging waves at S1 with a smaller drawdown in water surface as compared to outbound transits which can be attributed to vessel deceleration when entering the harbor.

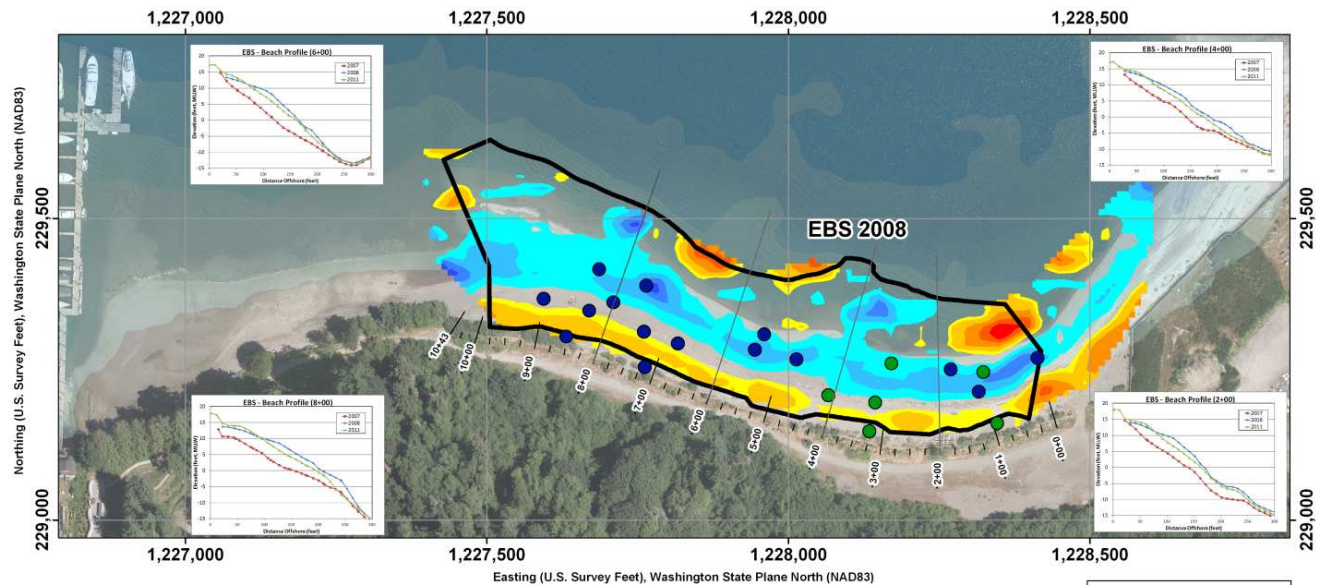

Figure 3. Elevation change from 2008 to 2011 on Exposure Barrier System (cool colors = erosion; warm = accretion)

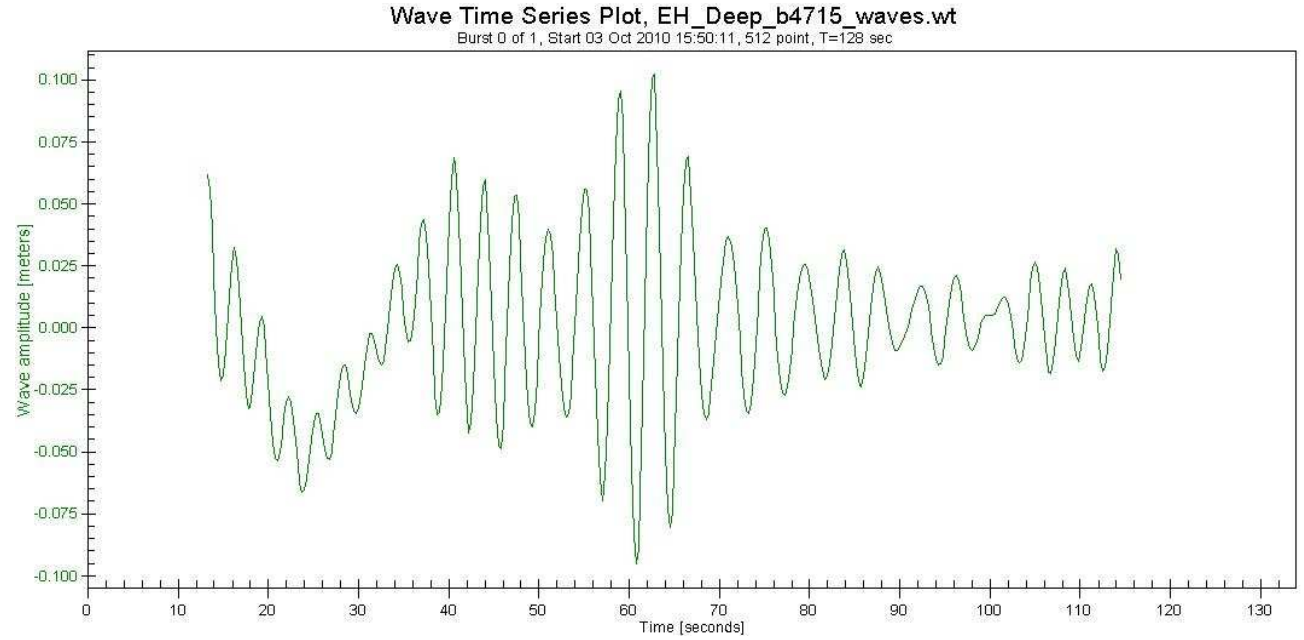

Figure 4. Outbound ferry water surface elevation $\left(H_{s}=0.15 \mathrm{~m} ; T_{p}=4 \mathrm{sec}\right)$

Grain size data was collected in October 2011 (HDR et al. 2012). In general all samples analyzed indicate the sediment comprising the cap is considered poorly sorted, or indicative of a wide range in grain sizes. As shown in Figure 5, 3 of the 36 samples collected over the sediment cap have a negative skewness indicating a potentially erosive environment. Samples with negative skewness all occurred on the Phase I cap. One of the samples was located under the ferry sailing line and the other two were located near the southern boundary of the Phase I cap near the North Shoal area.

\section{NUMERICAL MODELING ANAYLSIS}

SWASH-2D is finite difference phase resolving model used to predict waves and currents generated by vessels moving at subcritical, transcritical and supercritical speeds in restricted waterways; it is an extension of BOUSS-2D, a comprehensive numerical model for nearshore wave transformation, based on Boussinesq-type equations for wave propagation in intermediate water depths (Nwogu and Demirbilek 2001; Nwogu 2007). 


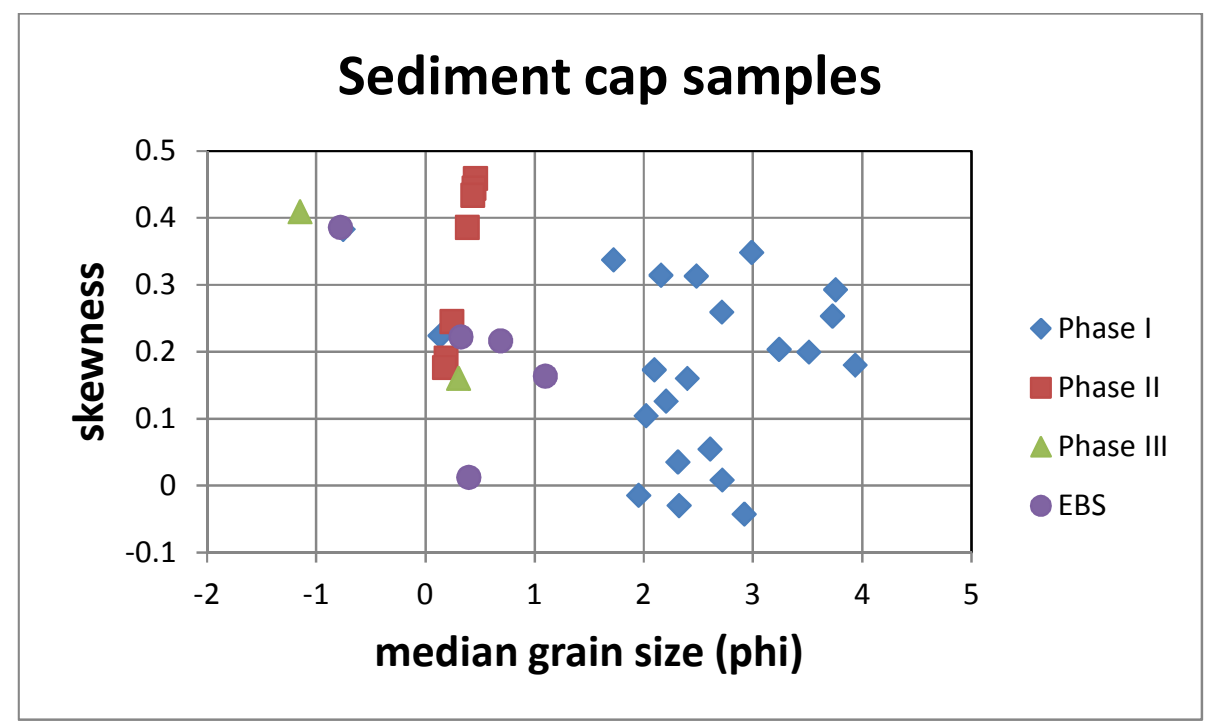

Figure 5. Sediment cap grain size analysis from 2011 sampling

\section{Model setup and validation}

SWASH-2D is employed to simulate a typical WSDOT ferry transiting through Eagle Harbor. The ferry is a Jumbo Mark II Class with a length of 140.2 meters, a beam of 27.4 meters and draft of 5.2 meters. The hull geometry of the M/V Wenatchee ferry was panelized into a mesh to force the initial pressure disturbance generated from the vessels hull. Bathymetry from NOAA (2009) was used to generate the model grid for Eagle Harbor. Both inbound and outbound transits were simulated in the model and compared with the observed field data.

The sailing line was specified in the model with available global positioning system (GPS) data collected onboard the $\mathrm{M} / \mathrm{V}$ Wenatchee. These data confirm the inbound speed of the $\mathrm{M} / \mathrm{V}$ Wenatchee slowed to approximately $6.2 \mathrm{~m} / \mathrm{s}$ (12 knots) is it entered the mouth of Eagle Harbor. These data show the ferry accelerates to over 6.7 knots (13 knots) prior to exiting the harbor during an outbound transit. The model was calibrated by varying the ship speed in the model and comparing the bottom pressure time series to the observed data at S1. Turbulent mixing was evident near the propeller of the ferry. Thus in the near field a viscosity coefficient was utilized to represent vertical mixing and wake dissipation processes. Figures 6 and 7 show 30 second snapshots of the modeled water surface elevation for inbound and outbound transits. The associated wake is composed of divergent waves from the sides of the hull and transverse waves in the lee. As shown in Figure 8 an important observation is the large drawdown (min bottom pressure $=-0.15 \mathrm{dbar}$ ) in water level at $\mathrm{S} 1$ during an outbound transit as the vessel accelerates. However the diverging waves do not reach the southern shoreline of the harbor and are directly primarily at North Shoal. In contrast, the inbound transit shows less of an initial drawdown near S1 (min pressure $=-0.05 \mathrm{dbar}$ ) but results in more wave energy directed toward the southern harbor shoreline and EBS. Figures 9 and 10 compare calculated versus observed data at S1 for inbound and outbound ferry transits. In general the model performs well, but overestimates the initial rise in water level. However the model accurately represents the shape of the wave and the magnitude of drawdown observed. 

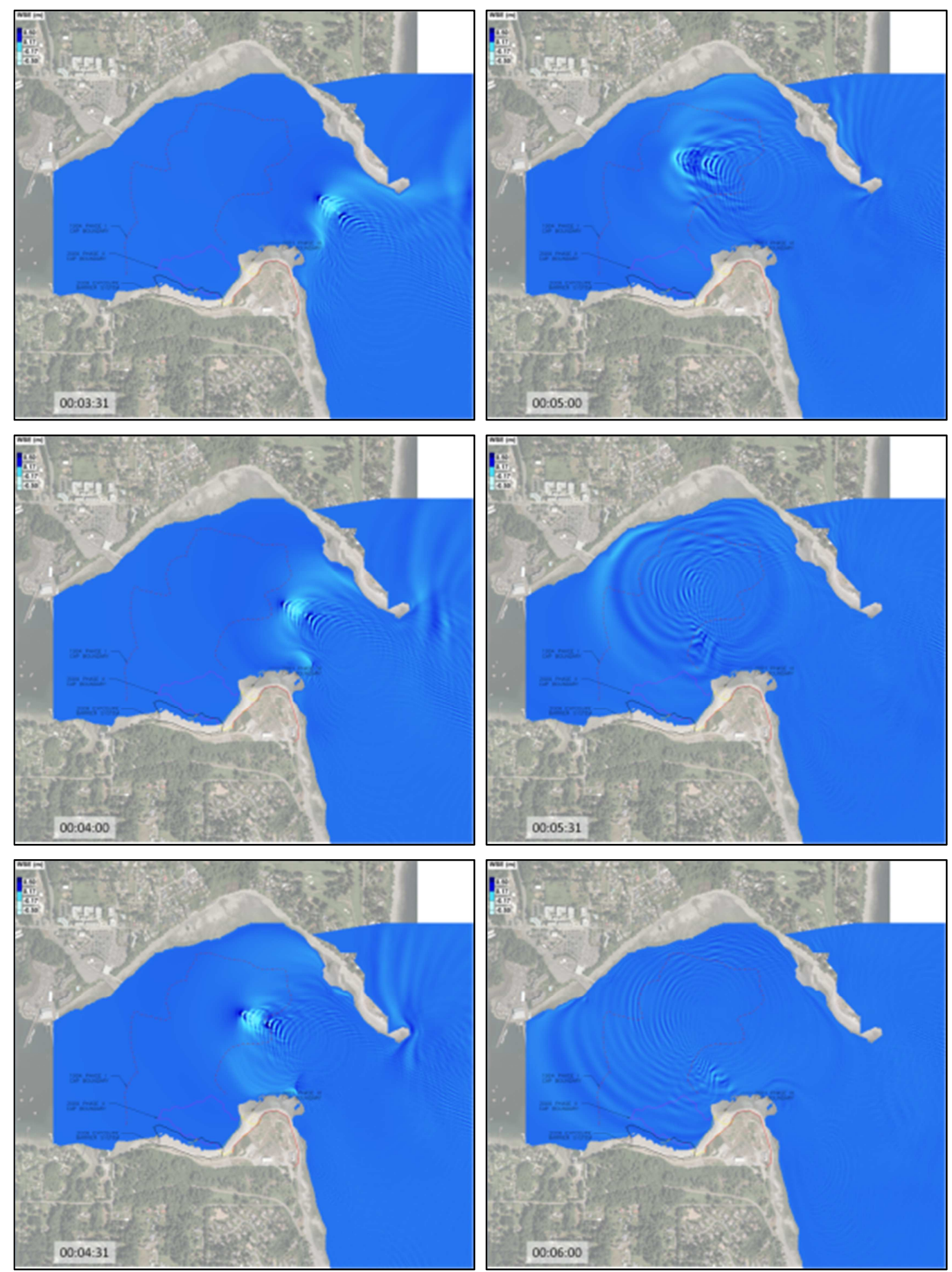

Figure 6. SWASH-2D computed water surface elevation snapshots for M/V Wenatchee inbound transit 

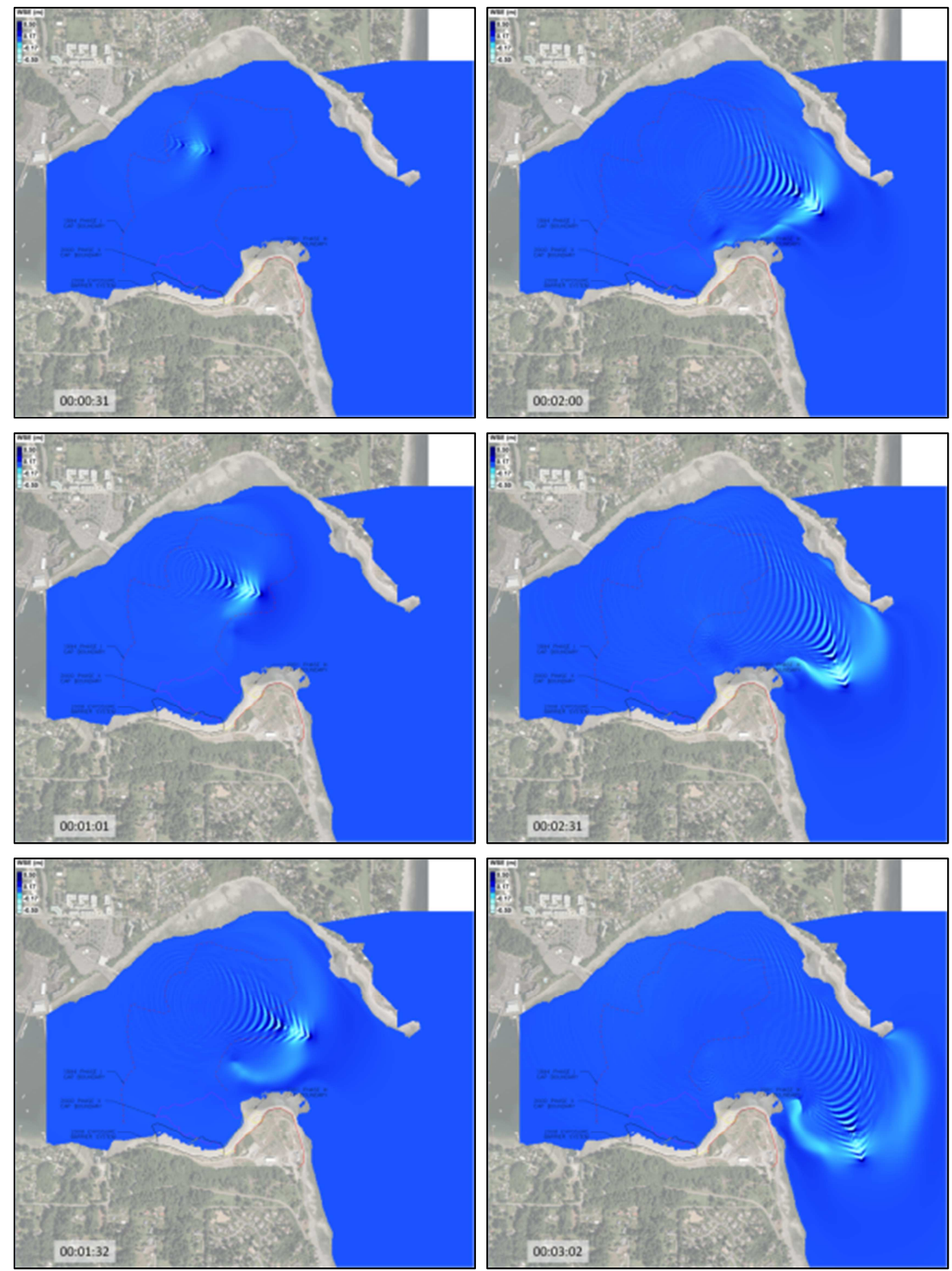

Figure 7. SWASH-2D computed water surface elevation snapshots for M/V Wenatchee outbound transit 


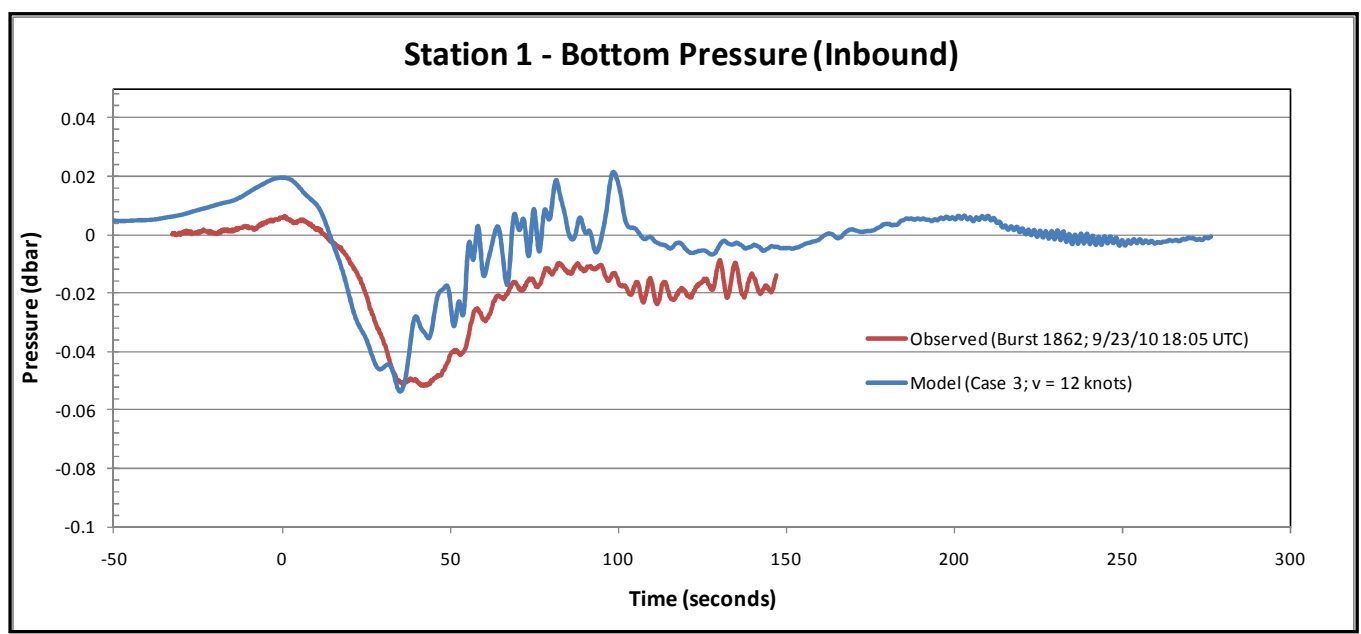

Figure 8. SWASH-2D versus measured bottom pressure (Inbound transit velocity of 12 knots)

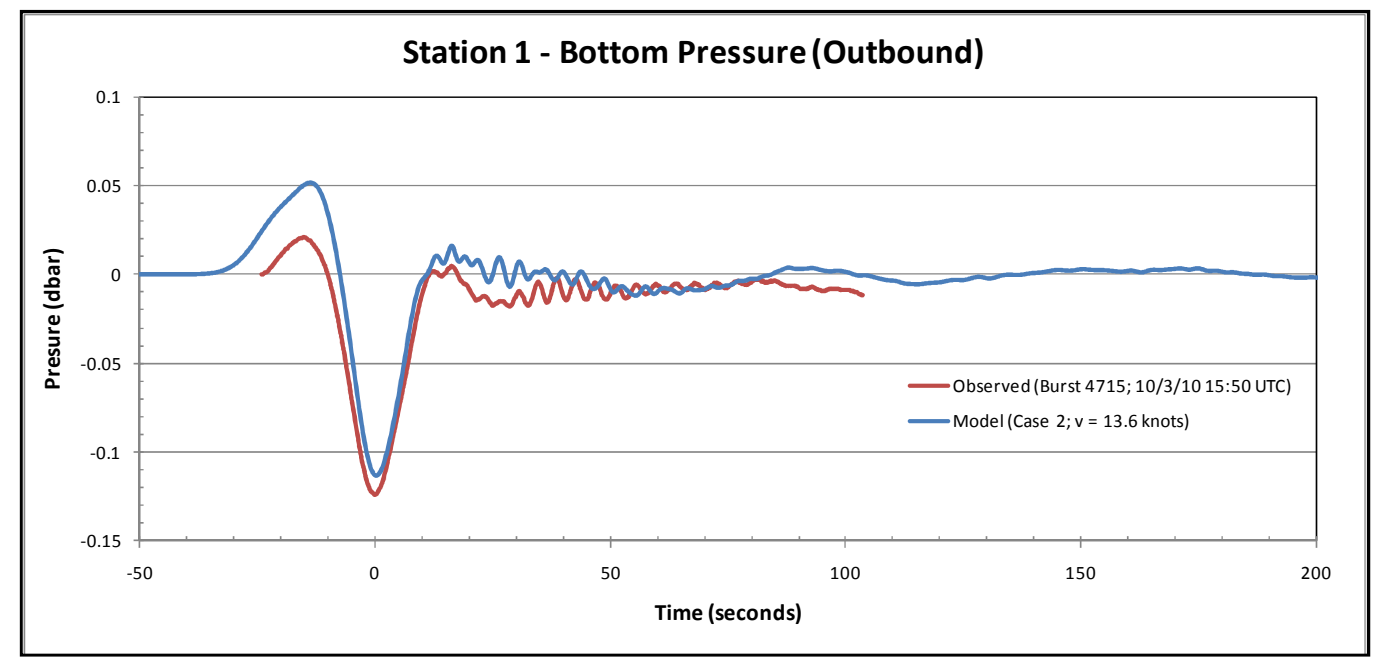

Figure 9.SWASH-2D versus measured bottom pressure (Outbound transit velocity of 13.6 knots)

\section{SEDIMENT MOBILITY}

Sediment particle motion is initiated when the critical shear stress on the seabed is exceeded. The critical shear stress for incipient motion is expressed as:

$$
\tau_{c}=\left(\rho_{s}-\rho_{w}\right) g d_{50} \theta_{c}
$$

where $\rho_{s}$ is the sediment density, $\rho_{w}$ is the water density, $g$ is gravitational acceleration, and $\theta_{c}$ is the critical Shields parameter, which is a function of the Reynolds number $(R)$. The critical Shields parameter is computed using the explicit formulation from Cao et al. (2006), as:

$$
\begin{array}{lr}
\theta_{c}=0.1414 R^{-0.2306}, & R<6.61 \\
\theta_{c}=\frac{\left[1+\left(0.0223 R^{2.8358}\right)\right]^{0.3542}}{3.0946 R^{0.6769}}, & 6.61<R<282.84 \\
\theta_{c}=0.045, & R>282.84
\end{array}
$$


The computed range in critical shear stress for incipient motion of cap material using sediment properties from the October 2011 sediment sample data is listed in Table 2. The Phase I cap was comprised of dredge material from the Snohomish River navigation channel near Everett, WA. The Phase II and III intertidal caps consisted primarily of sand to gravel and originated from the Glacier Northwest quarry in DuPont, WA. The 2008 Exposure Barrier System was constructed as a three layer (sand, cobble, geotextile) composite with the top 0.6 meter sand layer exposed to wave action. The wave induced bed shear stress $\left(\tau_{b}\right)$ is related to the near bed orbital velocity amplitude $\left(U_{w}\right)$ under a wave, and is computed as:

$$
U_{w}=\frac{g H k T}{4 \pi \cosh \langle k d\rangle}
$$

where $g$ is gravitational acceleration, $H$ is wave height, $T$ is wave period, $d$ is water depth. And $k$ is wavenumber $(k=2 \pi / L)$. The wave induced bed shear stress is then computed as:

$$
\tau_{b}=\frac{1}{2} \rho_{w} f_{w} U_{w}^{2}
$$

where the wave friction factor is specified according to Nielsen (1992) as:

$$
\begin{gathered}
f_{w}=e^{5.5\left(R^{-0.2}\right)-6.3} \\
R=\frac{U_{w} T}{2 \pi k_{s d}}
\end{gathered}
$$

Figures 10 and 11 show the calculated maximum bed shear stress for inbound and outbound ferry transits respectively. Maximum bed shear stresses above $1 \mathrm{~Pa}$ are shown in color. By analyzing the ratio of $\tau_{\mathrm{b}} / \tau_{\mathrm{c}}$ from SWASH-2D it is found the most probable region for cap sediment mobility is on the east side of the Phase I cap within a 30 meter swath of the ferry sailing line, where the predicted bed shear stress is $\tau_{b}>100 \mathrm{~Pa}$ and the critical shear stress $\tau_{c}$ is 0.1 to $0.4 \mathrm{~Pa}$. Under these bed stresses a suitable median grain size to retain stability would need to be approximately $d_{50}=150 \mathrm{~mm}$. The results also indicate inbound ferry transits generate the greatest potential for sediment mobility near the mouth of the harbor, while the outbound ferry transits generate the greatest potential for sediment mobility inside the harbor on the southern shoreline near the EBS. In the EBS and Phase II caps the calculated bed stresses exceed $1 \mathrm{~Pa}$ while the critical shear stress varies from 0.4 to $2.1 \mathrm{~Pa}$, indicating the possibility for mobilizing the finer fraction of sediments comprising these caps.

\begin{tabular}{|l|l|l|l|l|l|l|}
\hline \multicolumn{2}{|c|}{ Table 2. Sediment characteristics of 2011 sediment cap grab samples collected in Eagle Harbor } \\
\hline $\begin{array}{l}\text { Cap } \\
\text { Construction }\end{array}$ & $\begin{array}{l}\text { Cap } \\
\text { Area, } \\
\text { (ha) }\end{array}$ & $\begin{array}{l}\text { Design } \\
\text { Cap } \\
\text { Thickness, } \\
\text { (meters) }\end{array}$ & Material Source & $\begin{array}{l}\text { Median } \\
\text { grain size } \\
(\mathbf{m m})\end{array}$ & $\begin{array}{l}\text { Material } \\
\text { Classification }\end{array}$ & $\begin{array}{l}\text { Critical Shear } \\
\text { Stress (Pa) }\end{array}$ \\
\hline Phase I & 30.1 & 0.9 & Snohomish River & $0.02-0.30$ & $\begin{array}{l}\text { silt to medium } \\
\text { sand }\end{array}$ & $0.1-0.4$ \\
\hline Phase II & 4.4 & $0.3-3.0$ & $\begin{array}{l}\text { Glacier NW } \\
\text { Quarry }\end{array}$ & $0.13-2.52$ & $\begin{array}{l}\text { Fine to coarse } \\
\text { sand }\end{array}$ & $0.4-2.1$ \\
\hline Phase III & 1.1 & $0.3-3.0$ & $\begin{array}{l}\text { Glacier NW } \\
\text { Quarry }\end{array}$ & $0.81-2.21$ & coarse sand & $0.6-1.6$ \\
\hline EBS & 2.1 & 0.6 & $\begin{array}{l}\text { Glacier NW } \\
\text { Quarry }\end{array}$ & $0.62-1.71$ & coarse sand & $0.4-1.6$ \\
\hline
\end{tabular}




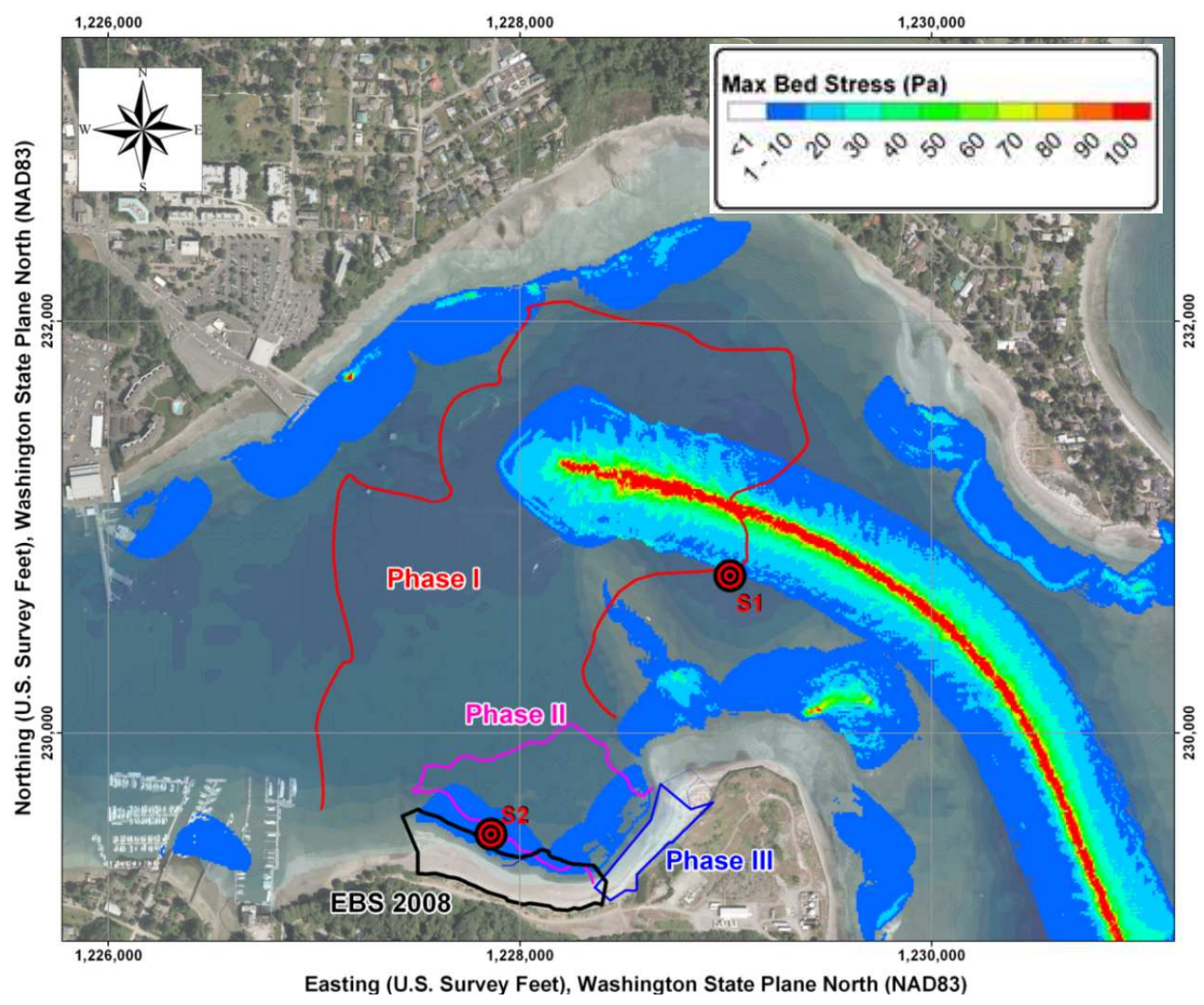

Figure 10. Maximum computed bed stress for outbound ferry transit

\section{CONCLUSIONS}

The SWASH-2D model was employed to calculate bed shear stresses over the Wyckoff/Eagle Harbor sediment chemical isolation cap from tidal and wave generated currents. Model results coupled with grain size data from recent 2011 sampling were used to identify regions in the existing cap where sediments have potential for erosion. Model results indicate ferry wake has a relatively high potential of mobilizing Phase I cap materials due to the combination of fine grained sediments comprising the cap and large bed shear stress generated in the immediate vicinity of the ferry sailing line. Areas with potential for sediment mobility of finer sediment fractions were also found in the Phase II and Expose Barrier System. As a result of this analysis the USACE has been tasked by USEPA to evaluate the feasibility of several alternatives to address the instability of the Phase I cap in the vicinity of the ferry sailing line as well as strategies for enhancing the performance of the Exposure Barrier system. 


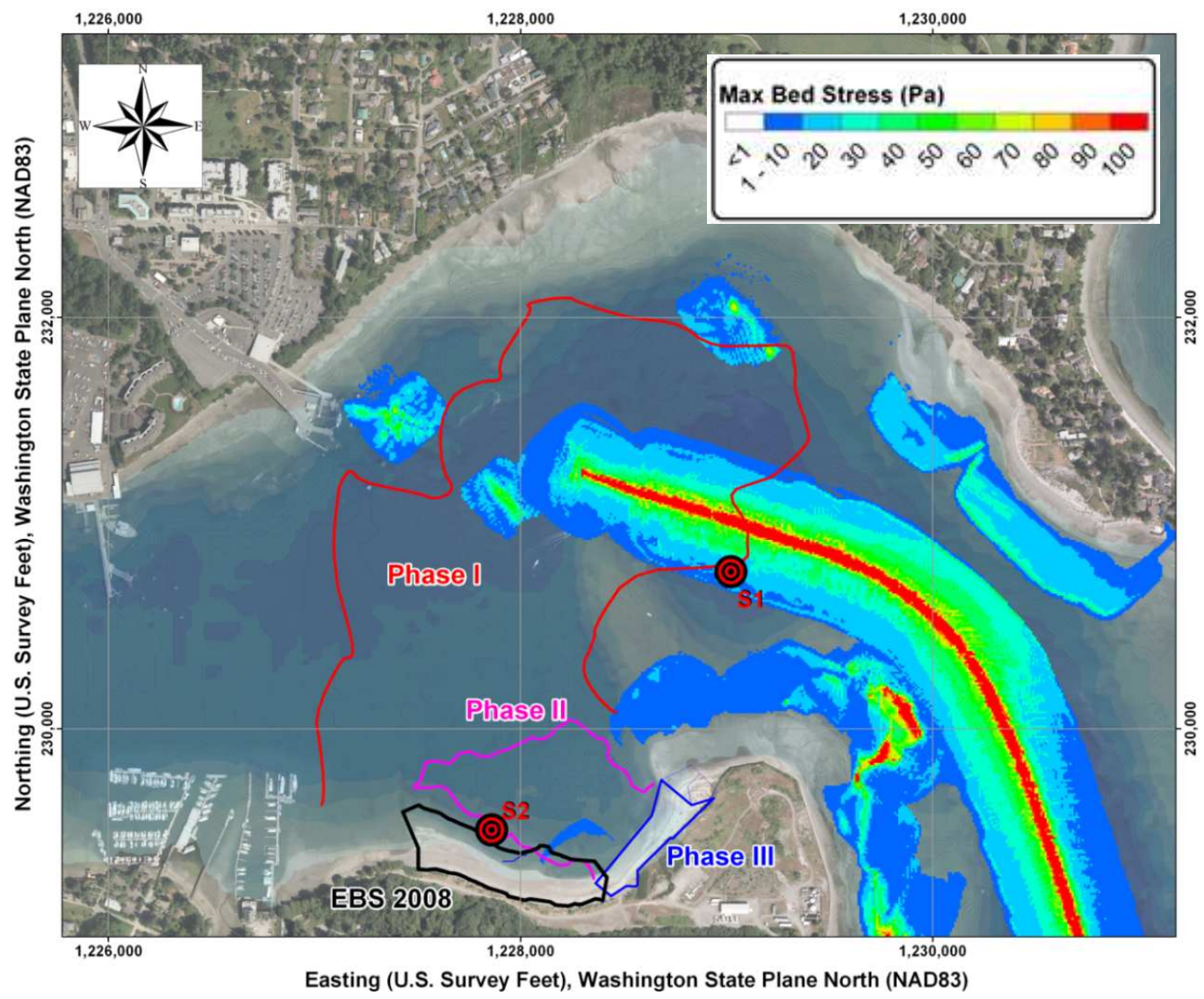

Figure 11. Maximum computed bed stress for inbound ferry transit

\section{REFERENCES}

Cao, Z, Pender, G., Meng, J. 2006. Explicit formulation of the Shields Diagram for incipient motion of sediment. J. Hydraulic. Eng. Technical Note. DOI: 10.1061(ASCE)0733-9429(2006)132:10(1097)

CH2MHILL 2006. West Beach Investigation Data Evaluation Report. Wyckoff/Eagle Harbor Superfund Site. Bainbridge Island, Washington. November 2006. Contract No. 68-S7-04-01.

CH2MHILL 2007. Design Basis for West Beach Cap. Technical Memorandum. Preparation date October 04, 2006. Project Number 316783.DE.05.

HDR Engineering Inc., Science and Engineering for the Environment LLC, Ken Taylor Associates Inc. 2012. Final 2011 Year 17 Monitoring Report. East Harbor Operable Unit - Wyckoff/Eagle Harbor Superfund Site.

NOAA. 2009. Approaches to Elliott Bay Skiff Point to Alki Point. Survey H12025 - April, 2009. NOAA Ship RAINER.

Nielsen. P. Coastal Bottom Boundary Layers and Sediment Transport. World Scientific, Singapore, $324 \mathrm{pp}$.

Nwogu, O.G., and Demirbilek, Z. 2001. BOUSS-2D: A Boussinesq wave model for coastal regions and harbors. Technical Report ERDC/CHL TR-01-25, U.S. Army Engineer Research and Development Center, Vicksburg, MS.

Nwogu, O., 2007. Numerical modeling of waves generated by high-speed vessels in shallow water with a coupled Boussinesq-Panel method. Proc. 9th Int. Conf. on Num. Ship Hydrodynamics, Ann Arbor, MI, 331-343. 